\section{$\underset{\text { hommes }}{\text { \& migrations }}$}

\section{Hommes \& migrations}

Revue française de référence sur les dynamiques

migratoires

$1304 \mid 2013$

Frontières

\title{
Yannick Haenel, Les Renards pâles,
}

Paris, Gallimard, 2013, 175 p., 16,90€.

\section{Mustapha Harzoune}

\section{Q OpenEdition \\ 1 Journals}

\section{Édition électronique}

URL : http://journals.openedition.org/hommesmigrations/2697

DOI : 10.4000/hommesmigrations.2697

ISSN : 2262-3353

\section{Éditeur}

Musée national de l'histoire de l'immigration

\section{Édition imprimée}

Date de publication : 1 octobre 2013

Pagination : 190

ISBN : 978-2-919040-24-7

ISSN : 1142-852X

\section{Référence électronique}

Mustapha Harzoune, «Yannick Haenel, Les Renards pâles, 》, Hommes \& migrations [En ligne], 1304 |

2013, mis en ligne le 20 mars 2014, consulté le 22 septembre 2020. URL : http://

journals.openedition.org/hommesmigrations/2697; DOI : https://doi.org/10.4000/

hommesmigrations.2697

Ce document a été généré automatiquement le 22 septembre 2020.

Tous droits réservés 


\title{
Yannick Haenel, Les Renards pâles,
}

Paris, Gallimard, 2013, 175 p., 16,90€.

\author{
Mustapha Harzoune
}

\section{RÉFÉRENCE}

Yannick Haenel, Les Renards pâles,

Paris, Gallimard, 2013, 175 p., 16,90€.

1 Premier temps : Jean Deichel décide de vivre dans sa voiture. Seul. Puis, à travers ses déambulations sur les pavés du XX $\mathrm{X}^{\mathrm{e}}$ arrondissement de Paris, à travers des inscriptions sur les murs - "La société n'existe pas", "La France c'est le crime", "Identité = Malédiction", “ Dieu est noir" - et un étrange dessin - le renard pâle -, il déchiffre les signes d'une révolte à venir. Solitude, mots, émeute, mémoire révolutionnaire du pavé parisien ensemencée d'histoire coloniale et migratoire, identité et appartenance constituent les thèmes de ce roman-pamphlet, roman-manifeste cinglant à l'écriture puissante, qui invite à repenser, par la littérature, ce qui fait lien. Ce qui fait société.

2 Ces Renards pâles résonnent avec les paroles d'une chanson de la Commune - et cela tombe plutôt bien - signée Eugène Pottier et Max Rongier : Quand viendra-t-elle? Comme dans la chanson interprétée par Mouloudji, chez Haenel il est question des sacrifiés du système (les sans-emplois, sans-papiers, sans-logis...), pour dire non seulement le possible de la révolte mais sa nécessité : “L'émeute, au XXI ${ }^{e}$ siècle, est devenue le destin du monde." Une révolte portée par la puissance insurrectionnelle - puissance retrouvée ? des mots et de la poésie : "La déflagration qu'avec patience nous attendons, et qui seule à nos yeux est digne de troubler l'ordre du monde, ne se déclenche qu'avec la poésie."

3 "L'écoute des ombres", celles du Père-Lachaise et de la Commune, ressuscite les morts. Conséquence des temps modernes, cette mémoire retrouvée est remodelée par un éloge de la solitude et un héritage, l'héritage africain. "Que vous le vouliez ou non: un spectre hante la France c'est l'Afrique." L'émeute, portée par des sans-papiers arborant des masques dogons, est transfigurée par une figure de la mythologie dogon, le renard pâle, qui représente "la rupture ou l'autonomie", "le mauvais fils", "la mort de Dieu". Il invite à en 
finir avec le "renoncement", à retrouver "le langage du refus", à rétablir la politique et la poésie.

4 La solitude de Jean Deichel n'est pas celle de l'exclu, mais une solitude qui réinscrit chacun dans son histoire et dans le monde. "La solitude est un pays qui brûle", "la solitude est politique". Elle est retrouvailles, (re)conquête de soi, rupture avec la société, réinvention de l'appartenance et érection d'une nouvelle divinité. Place de la République, un baobab se substitue à la Marianne laïque !

5 À partir du "maléfice", du "mauvais ceil" d'un système dont "les immolations de chômeurs" figurent l'image terminale, Haenel cuisine l'insurrection aux feux de la Commune, du colonialisme et de l'immigration, inocule quelques doses de spiritualité et de traditions africaines dans le cartésianisme occidental pour prendre à bras-le-corps les thèmes de l'identité, de l'appartenance, de la frontière.

6 Les manifestants-émeutiers, les "Dogons-communards", défilent masqués (rappelant les Anonymous). Parce que "la société a besoin que nous ayons une identité pour nous contrôler. Il faut en finir avec cette logique". L'anonymat ne rime pas avec uniformité mais annonce l'utopie d'un monde "débarrassé de l'identité", où "l'appartenance n'existe pas" et où "la communauté, si elle existe, déjoue la clôture". Les Renards pâles sont un roman allégorique qui invite à élargir l'espace et le temps de nos représentations. L'espace et le temps des possibles. 